\title{
W 19-1
}

特異な頭部CT,MRI 所見を呈した全身性エリテマトーデスの1例

○西下千春，的場謙一郎，梅川康弘，浅川徹 *, 宮脇昌二

(倉帴成人病センタ一内科，放射線科 *)

【症例】50歳女性. 31 歳よりレイノ現象, 32 歳時自己免疫性肝炎で入院・41歳頃より肥满, 糖尿病を合併し，関節痛，顔面紅斑が出現．抗DNA 抗体上昇と肝障害を絽り返す。平成 10 年 6 月左下腿静脈血栓で入院. 6 月末ょり複視, 7 月中旬左眼瞼下垂が出現 ・ 頭部 CT,MRI で大脳, 小脳, 脳幹部に最大 $8 \mathrm{~mm}$ 径のリング状に造影される結節状病变を無数に認めた。

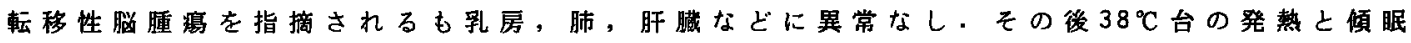
傾向, 項部硬直が出現. 髄液で蛋白增加, 単核球優位の細胞增多があるも, 結核菌PCR, 真菌，細菌など常時陰性でADA 13.2IU/1。フレド（PSL）20mg/ 日を維持し，抗生剂，抗真 菌郕，抗結核荗を投与した。7月下旬より混迷状態となり，PSL $40 \mathrm{mg} /$ 日へ增量したよ ころ短期間で意識清明となり，眼瞼下垂の改善と解熱をみた。その後高度の肝障害が出現 したため抗結核剤などを中止.さらに䯣液細胞数減少上項部硬直の消失を認めたため8月 下旬PSLを減量. 頭部MRI 所見は不变・9月上旬再度発熱上意識レイルが低下し, PSLを增 量するも昏睡亡なり痙級が頻発，单核球優位の艏液細胞增多が再度出現し，9月中旬永眠。

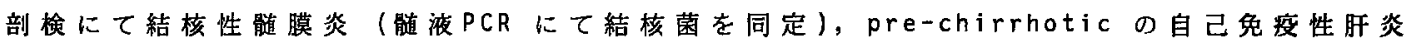
が存在したが, 中枢神経以外に結核病巣は認めなかった。当症例の頭部CT,MRI所見に類 似した報告例は見当たらずまたPSLに対して特異な反応性を示した症例と考えられた。

\section{W 19-2}

網膜静脈閉塞による眼底出血を合併した全身性エリテマトーデス（SLE）の1例 $\bigcirc$ 長崎宗网, 前川勝英, 山田秀樹, 藤本 隆, 土肥和紘 （奈良県立医科大学第 1 内科）

症例：72歳，女性，主訴：右視力の低下，現病歴：昭和 58年に関節痛，LE細胞陽性，抗 核抗体・抗DNA抗体の陽性，および光線過敏症から全身性エリテマトーデス（SLE）と診 断された。また，昭和 48年頃から口腔内乾燥症と眼乾燥症が出現しており，ローズベンガ ル試験の陽性と唾液腺造影の異常から二次性のシェーグレン症候群の合併例と診断された. SLEの活動性はプレドニゾロン（PSL） $30 \mathrm{mg} /$ 日で低下し，PSLを $5 \mathrm{mg} /$ 日に潮減されて外 来で経過が観察されていた．平成10年10月から右視力の低下を自覚し，当院の眼科で右網 膜静脈閉塞（BRVO）による眼底出血と診断された。入院時検查成績 : 検尿と血液学検查に 異常はない，血液凝固学検査は，正常範囲にあった。免疫血清学検查では，抗核抗体が20 倍（speckled型）の陽性以外に，抗リン脂質抗体などの他の自己抗体は陰性であった．眼底 検查で右BRVOによる眼底出血が確認されたが, 高血圧あるいは糖尿病性の変化は認められ なかった。 入院後経過 : プロスタグランディン $\mathrm{E}_{1} 20 \mu \mathrm{g} /$ 日の 5 日間静脈内投与によって， 眼底の出血病変と視力は軽度の改善を示した，結語：本例は，BRVOによる眼底出血を発症 したSLE例である．網膜動脈に明らかな高血圧あるいは糖尿病性の変化がみられなかったの で，BRVOの病因はSLEの血管病変に関連しているものと考えられる. 
W 19-3

高次㜆機能障害を呈し興味深い経過を示したCNS - I upus のー例

○清滝昌哉 1 ，本島新司 2

(1奄田総合病院原病内科，2アレルギー感染症内科）

（目的）器留的脳障害を示すCNS-I upusは予後不良といわれるが，MRIで病变があ り，高次脳機能障害を示しながら自然軽快し長期に経過钼祭したSLE症例を経駼した。

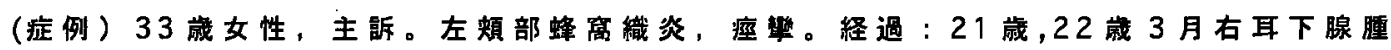
脹で切開排朖を受ける。8月左下䫑の腫脹あり8/15口腔外科入院した。34.5kgで腹

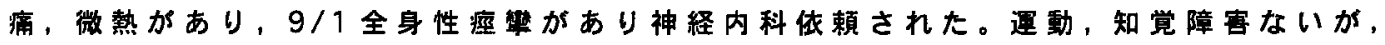
左手失書，拮抗失行，半側空間無視，地㕵的失見当，左下 $1 / 4$ 半盲を示した。MRIで T2強調像で脳梁及び右後頭葉で高信号域を認め，T1強調像で Gd 造影を示した。神経 所見は 2 䢙間で半盲を除き轾快しMRI所見も改善した。ANA2560x,RNP64x,Sm32x， SS-A16x，DNA19u，IgG3361，C321，C46などよりSLEの診断かついて 9/25より PSL40mgで開始し $11 / 11$ 退院した。その後PSL5mg投与中の 23 藏 1 月両胸水，心 液眝留で入院しPSL40mgの治療で軽快した。その後当科外来で治療し，低補体， 自己抗体高值にたいし免疫抑制剂の併用を行ったが充分使えず，28藏で白内障手術， 29 歳で精㽷病併発で入院した。30歳より左化滕性耳下腺炎で每入年入院し33歲で耳下 腺を摘出した。蛋白尿は隍性であったが 28 歳頃より出没し,やがて常に陽性となり 20-50mg/dl と少量であったが Cr 1.8，BUN49上䑁機能が悪化した。（結語）SLEの CNS 病変にはself-limitedのものがあるようだが, 腎病変は替在的に㕠行性である。

\section{W 19-4}

悪性症候群を併発した中枢神経性ループスの一例

○原 重雄、北村曜子、大木康弘、横田雅史、田上哲夫、白矢勝子、香取秀幸、 乳原善文、竹本文美、原 茂子、山田 明 ${ }^{1)}$ 、中瀬浩史 ${ }^{2)}$

1) 虎の門病院リウマチ膠原病科、2) 同神経内科

【症例】 51 歳女性。1981 年にRA、1982 年にITP と診断されている。1986 年に全身性エ リテマトーデス(SLE)と診断され、プレドニゾロン $20 \mathrm{mg}$ 隔日・アザチオプリン $50 \mathrm{mg} /$ 日投与 を受けていた。1998 年 12 月 1 日より感冒症状出現し、その後不穏、失見当識、幻覚、意識 混濁などが出現したため 12 月 10 日入院。髄液検査にてリンパ球優位の白血球增加を認め、 脳波上微小䊂波が認められた。ウィルス性脳脊髄炎疑いにて 症状は軽快しなかった。血清学的にはSLE の増悪を示す所見は無かったが、頭部 MRIで中 枢神経系(CNS)ループスに合致する所見があり、ステロイドパルス療法を施行した。一方、 不穞状態の鎮静のためハロペリドールを投与したところ、高熱・CK の上昇・筋固縮が出現 し悪性症候群の診断にてダントリウムを投与し解熱した。しかし再び発熱がみられ意識障害 の改善がみられないため、ステロイドパルス療法を再度施行して解熱、精神症状及び全身状 態の改善を認め退院となった。

【考察】本症例は SLEの患者に精神神経症状が出現し、最終的に CNS ループスと診断され た。鑑別診断として脳炎・脳血栓・ステロイド精神病等考えられたが、向精神薬による悪性 症候群のために臨床症状が修飾され診断・治療に苦慮した。CNS ループスの治療経過中に悪 性症候群を合併した報告は今までみられない。 


\section{W 19-5}

抗リン脂質抗体陽性全身性エリテマトーデスに合併した難治性血栓性微小血管症性 溶血性貣血に対しシクロホスファミド間歇静注療法が著効を示した一例

○赤荻 淳, 浜 信昭, 山田秀裕, 松田隆秀, 鈴木康夫, 市川陽一

（聖マリアンナ医科大学 内科学：リウマチ・膠原病・アレルギー）

【症例】27水女性.【主訴】発熱, 全身倦怠感.【現病歴】1999年1月中旬より，38 ${ }^{\circ} \mathrm{C}$ の発熱，全身倦意感，四肢の紫斑が出現したため精查加療目的で本院に入院した. 口腔 内潰瘍と口腔粘膜出血斑を認め, リンパ球減少 $(1020 / \mu 1)$, 血小板減少 $(5000 / \mu \mid)$, 溶血性貧血 (Hgb $4.1 \mathrm{~g} / \mathrm{dl}$, 網状赤血球 $281 \%$, 破砕赤血球 3+, LDH 2992 IU/I, クーム ス試験陰性, ハプトグロビン<10 m g/dl), 低補体血症, 抗核抗体陽性 (2560倍), 抗 DNA 抗体陽性 (180 IU/ml), PAlgG $16800 \mathrm{ng} / 10^{7} \mathrm{cell}$ (抗血小板抗体陰性), 抗リン 脂質抗体陽性から，血栓性微小血管症性溶血性貧血 (TMHA) を合併した全身性エリテマ トーデス (SLE) と診断, ステロイド大量療法と新鮮凍結血漿を用いた血鼎交換療法 (PE) を開始した．PEを連日施行し効果が認められたため隔日施行としたところ，血小板の再 減少を認め, ステロイドパルス療法と抗血小板療法を併用した．その後も血小板数の改善 が不十分でPEからの離脱が困難だったため, シクロホスファミド間歇静注療法 (IVCY) を施行した. 血小板数は正常化しPEからの離脱も可能となった.

抗リン脂質抗体陽性SLEに合併した治療抵抗性のTMHAに対しIVCYが著効を示した一 例を経験した. SLE合併TMHAの病態と治療法を考えるうえで貴重な症例と考えられたた め報告する。 


\section{W 20-1}

組織学的に急性肝炎と非化膿性胆管炎の病変が混在した混合性結合組織病(MCTD)の 1 例 奈良県立医科大学第 1 内科 $\bigcirc$ 上野和枝, 藤本 隆, 土肥和紘 金沢大学第 2 病理学 中沼 安二

症例：28歳，女性。主訴：発熱と全身倦怠感。既往歴・家族歴 : 特記することはない. 現病歴: 平成9年10月頃から関節痛を自覚していたが, 近医でのNSAIDSの処方によって改 善した. 同年12月頃からレイノー症状が出現し，同時に手指のソーセージ様腫脹に気付い た. 精査を目的として平成10年3月に当科に紹介された。レイノ一症状，手指のソーセージ 様腫脹，抗U1-RNP抗体陽性，多発関節炎，および手指に限局した皮膚硬化が認められたの で，SLEと強皮症様の所見を示すMCTDと診断された。数日前から発熱, 食欲不振, およ び全身倦急感が出現しており，血液検査で肝機能障害を示したので再入院した，身体所見： 体温 $40^{\circ} \mathrm{C}$, 結膜に黄染はない。上腹部に圧痛を認めるが, 肝を触知しない。入院時検查成 績: 検尿と血液学㭘查に異常はなかった。血液生化学検查では, 逸脱酵素に高度の上昇

(GOT 3,712, GPT 2,246, LDH 5,907) が認められた. 免疫血清学検查では, 抗U1-RNP抗 体の陽性を除いて，抗ミトコンドリア抗体などの他の自己抗体はすべて陰性であった．ま た，A，B，C，E，およびG肝炎ウイルス抗体も陰性であった。第11病日に施行した肝生榆 所見では，急性肝炎回復期と非化膿性胆管炎の病変が混在していた。約 2 週後には, 肝機 能は正常範囲に回復した. 結語：本例は，組織学的に非化膿性胆管炎と急性肝炎の湿在が みられたMCTD例であり，肝炎ウイルスおよび抗U1-RNP抗体以外の自己抗体が陰性である ことから，MCTDに合併したまれな自己免疫性肝炎症例と考えられる.

\section{W 20-2}

SLE 治療中にCrohn 病を診断された 1 例

○松本憲二 ${ }^{1}$, 大久保忠信 ${ }^{1}$, 大野 滋 ${ }^{1}$, 上田敦久 ${ }^{1}$, 出口治子 ${ }^{1}$, 萩原恵里 ${ }^{1}$, 青木昭子 ${ }^{1}$, 白井 輝 ${ }^{1}$, 梅沢 正 ${ }^{2}$, 関原久彦 ${ }^{2}$, 長岡章平 ${ }^{3}$, 石ヶ坪良明 ${ }^{1}$

( ${ }^{1}$ 横浜市立大学第 1 内科, ${ }^{2}$ 同第 3 内科, ${ }^{3}$ 横浜南共済病院师戏科)

症例は 25 歳女性. 平成 6 年 11 月 Sjögren 症候群と診断され、以後当科でフォローし ていた。平成 10 年 10 月、蝶形紅斑, 尿蛋白, 下腿の浮腫が出現し入院となった。入院 時尿蛋白 $12 \mathrm{~g} / \mathrm{d}$ ay 、血清アルブミン $1.5 \mathrm{~g} / \mathrm{d} 7$ とネフローゼ症候であり、抗核抗体 640 倍， 抗 DNA 抗体 28.0, 抗 Sm 抗体 10.6 と診断基準を満たし、SLEと診断した。腎病変は生検 でループス腎炎 (class Vb) であった。入院第3日目と15 日目から、それぞれ mPSL $500 \mathrm{mg}$ $\times 3$ 日間のステロイドパルス療法を 2 クール施行し、以後 PSL $30 \mathrm{mg}$ の維持量で蝶形紅斑 の消退と尿蛋白の減少を認めた。入院前からの下血があり、Hb も徐々に低下したため消 化管出血の検索を行った。11月に施行した下部消化管内視鏡検查で回腸終末部と結腸肝 彎曲部の縦走漬瘍を認め、小腸二重造影では上部回腸に cobble stone appearance とCrohn 病に特徵的な所見を認めた。生検では肉芽腫は認めなかったが、Crohon 病と診断され 5-ASAによる治療を開始し、下血および貧血の改善を認めた。SLEはもとよりCrohn病も 自己免疫の異常が関与していると考えられているが、その 2 疾患の合併例の報告は稀で あり、文献的考察を加えて報告する。 


\section{W 20-3}

著明な腸管浮腫を呈した感染性腸炎合併 S L E の 1 剖检例

○尾原幹辟，林雅子，武内徹，槙野茂樹

(大阪医科大学第一内科)

症例は19歳女性。平成6年レイノ一症状、7年4月心呈水眝留で近医入腙、結核性心膜炎 とされステロイドを含む治療で軽快。10月再度心索水眝留し抗核抗体陽性、補体低值、蛋 白尿を認め当院転院。抗dSDNA抗体高值、抗RNP抗体・抗リン脂筫抗体陽性にてSLEと診断 フレドニン $60 \mathrm{mg}$ より加療し軽快退院。8年10月蝶型紅斑出現しフレドニン增量にて軽快。 9 年 2 月全身倦急と食思不振出現、4日より腹痛、6日嘔気、嘔吐出現し来院、WBC39000の ため腹膜炎を疑い入院。蝶型紅斑を認めるも補体正常。X線で小腸カスとニボー、CTにて 著明な腸管肥厚を認め、抗菌郕投与とフレドニン增量で対処するも改善せす、８日には血 圧低下、補体低下が見られ、血墏交換、ステロイドパルス施行するも12日死亡。剖検で大 腸全長に著明な壁肥厚。漿膜面に出血とフィフリン析出。粘膜面に溈膜と潰煌の形成、偽 膜にグラム陽性球菌の繁殖。粘膜下層から筋層にかけて高度の浮腫。また、陳旧性心外膜 炎とメサンギウム增殖性腎炎が認められた。近年、SLEで血管炎に基づく腹膜炎や膀胱炎 の報告があり著明な腸管浮腫を伴う例も数例報告されている。また、心膜炎のあるSLEで 腹膜炎合併が多いとの報告もあり漿膜炎を起しやすい病型が考えられる。本例は剖検所見 で血管炎を認めず明らかな腸管感染があったが、初発症状に腸炎症状なく、心膜炎発症で 腸管浮腫が著明でありSLEで腹膜炎を起す機序の関与が推察され興味深いと考え報告する。

\section{W 20-4}

ステロイドパルス療法開始後に急性膵炎を発症したS L E 22 症例

○前澤玲華 武田昭 山田一成 檜山貴子 児玉国洋 中島宏和 福島康次 沼尾利郎 福田健

<獨協医科大学 呼吸器・アレルギー内科 $>$

症例 $1: 47$ 歳、女性。昭和 53 年発症のS L E。平成 10 年 11 月発熱、上腹部痛、 肝機能障害、低補体血症を認めS L E の再燃を考え入院。入院時の腹部エコーでは、明か な異常は認めず。急性ループス肺臓炎をきたしステロイドパルス療法（メチルプレドニゾ ロン $1 \mathrm{~g}$ を 3 日間) 施行。 2 日目より激しい上腹部痛が出現した。腹部エコー、腹部 C T 上、膵腫大と腹水を認め急性膵炎と診断した。ステロイド減量により改善を示した。その 後、クモ膜下出血により死亡。

症例 $2: 28$ 歳、女性。平成 10 年 8 月発症のS L E。平成 10 年 12 月発熱、呼吸困 難のため入院となる。ループス腎炎の発症を認め、ステロイドパルス療法（同上）施行。 5 日目に血中アミラーゼの上昇を認め、腹部 C T を施行した。膵仮性囊胞、膵腫大を認め 急性膵炎と診断した。ステロイド減量により改善している。

考察：S L Eにおける膵炎発症の機序としては血管炎によるもの、ステロイド療法に起 因するもの等、種々の要因が考えらてれる。2症例之もこれまで膵炎の既往はなく、飲酒 等の一般的な誘因も認められていない。今回、S L E における急性膵炎発症の成因に関し、 病理組織学的検討並びに文献的考察を加えて報告する。 


\section{W 20-5}

$\mathrm{CD}^{+} \mathrm{CD}^{+} 6^{+} \mathrm{T}$ 細胞が増加した自己免疫性肝炎を合併した全身性エリテマトーデスの

一例

○佐藤英智、岡崎仁昭、岩本雅弘、平田大介、狩野庄吾、穔田清次

（自治医大アレルギー膠原病科）

「症例」61歳女性。平成11年2月、血小板減少と肝機能障害とで入院。蝶形紅斑、白血球減少 $(1900 / \mu \mathrm{l})$ ，血小板減少 $(32,000 / \mu \mathrm{l})$ 、抗核抗体陽性（640倍）、抗ds-DNA 抗体陽性 (119.4 $\mathrm{IU} / \mathrm{ml}$ ）から、全身性エリテマトーデス（SLE）と、また肝機能障害はALP/GPT<3.0、血清IgG 比 1.5、抗核抗体陽性、抗ミトコンドリア抗体と各種肝炎ウイルス抗体陰性、腹部エコー検查などか ら自己免疫性肝炎の合併と診断した。「方法」末梢・骨髄血単核球を各種抗体で三重染色し、ま た PMA・イオノマイシン刺激下でのサイトカイン（IL-2/LL-4/IFN- $\gamma$ ）産生をcytoplasmic 染色によ り、FACS-can で解析した。「結果」1）末梢血ではCD3 50.1\%、CD4 10.3\%、CD8 41.5\%、CD19

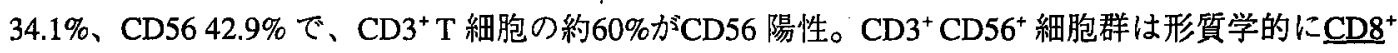

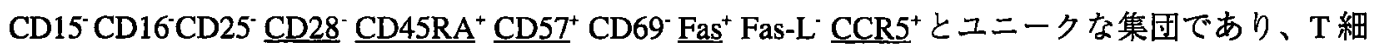
胞抗原レセプターの解析では、いわゆるNKT 細胞で高頻度に利用されるV $\alpha 24$ は陰性。2) サイ トカイン産生は $\mathrm{CD}^{+} \mathrm{CD}^{+} 6^{+} \mathrm{T}$ 細胞群では $\mathrm{CD} 3-\mathrm{CD}^{2} 6^{+} \mathrm{NK}$ 細胞群と同様にIFN- $\gamma$ のみ大量に産生。 $\mathrm{NK}$ 活性は $37 \%$ 。3）骨䯣ではCD3 ${ }^{+} \mathrm{CD} 56^{+} 0.9 \% 、 \mathrm{CD} 3^{+} \mathrm{CD} 56$ T 細胞群 $0.6 \%$ と、微少集団であった。 4）他の活動性の高いSLE 症例ではCD3 ${ }^{+} \mathrm{CD} 56^{+}$細胞群の増加は観察されなかった。「考察」本例 で増加した $\mathrm{CD} 3^{+} \mathrm{CD} 56^{+}$細胞群は、最近、ヒト肝臓内単核球で優位に存在することが報告されてお り、合併した自己免疫性肝炎との関連性が示唆された。 
W 21-1

脳血管障害を伴った若年性関節リウマチの一症例

○山本敬之 ${ }^{1.3}$ 、阿部 敬 ${ }^{1}$ 、小林歓和 ${ }^{1}$ 、赤池 淳 ${ }^{1}$ 、池田幸穗 ${ }^{1}$ 、細川歩1、下地英

樹 ${ }^{1} 、$ 酒井 基 ${ }^{1}$ 米沢和彦 ${ }^{1} 、$ 松谷 学 $^{1} 、$ 登坂松三 ${ }^{1} 、$ 今井浩三 ${ }^{2}$

( ${ }^{1}$ 市立釧路総合病院内科、札幌医大·第一内科、 ${ }^{3}$ 国療八雲病院神経内科)

若年性関節リウマチ(以下、JRA と略す)の経過中に中枢性血管炎を発症した極めて稀と考 えられる一症例を報告する。

症例は 16 歳男性。平成 9 年 12 月に発熱、関節痛を主訴に当科受診。左足関節の関節炎、 CRP 陽性、赤沈の亢進を認めたが、リウマトイド因子、抗核抗体、p-ANCAなど各種自己抗体は 陰性。厚生省研究班の若年性関節リウマチ診断の手引きによる診断基準を満たし、JRA の診 断にて少量のプレドニゾロン(以下、PSL と略す)使用中であった。

平成 10 年 10 月 21 日、関節炎の増悪と炎症反応の上昇を認め入院。10月28 日より頭痛、 高血圧が出現し、翌日には左の軽度眼瞼下垂、右の耳鳴り、および顔面筋の軽度筋力低下が 出現した。頭部 MRIにて右前頭葉と右小脳半球に血管炎の所見が諘められ、胸䯣 MRI では上 部胸髄の病変が疑われた。オージオグラムにて右の感音性難聴と診断された。レノグラムにて 右腎の血流障害を認め、血管造影で右腎血管の㹟寒·閉塞が確認された。PSL60mgに堌量し、 高血圧は持続したが、頭痛、眼瞼下垂は消失し顔面筋の筋力低下も軽快した。血液検査では 炎症反応の改善が得られた。頭部 MRI にて脳血管炎の所見も速やかに改善したことが確認さ れた。

\section{W 21-2}

虫さされにより皮膚潰瘍の増熏を認めたSjogren症候群の1例 ○角田慎一郎 ${ }^{1}$, 若杉春枝 ${ }^{1}$, 松下和彦 ${ }^{2}$, 元田 憲 ${ }^{1}$, 谷内江昭宏 ${ }^{3}$

${ }^{1}$ 横浜栄共済病院内科, ${ }^{2}$ 横浜栄共済病院病理部, ${ }^{3}$ 金沢大学医学部保健学科

症例は59歳，女性. 主訴は，皮膚潰瘍４40藏時より健康診断にてZTTの高値を指摘されたが，特 に精查せず．56歳時に高ガンマグロブリン血症( $4.1 \mathrm{~g} / \mathrm{dl}$ ), 腎障害(BUN34.2,Cr1.3)にて当科へ紹 介された. 抗核抗体640倍(Ho), 抗DNA抗体 $13 \mathrm{IU} / \mathrm{ml}$, 抗SSA抗体256倍以上で腎生検にて尿細管 間質障害を認め, Sjogren症候群とそ㧈に伴う間質性腎炎と診断し, 経口にてPredonine(PSL) $20 \mathrm{mg} /$ dayより開始した。 また，抗サイログロブリン抗体100以上，抗TPO抗体 30.0 以上で慢性甲 状腺炎の合併も認めた。 IgE8700で虫さされの刺し口が水泡化し, 皮膚生検にてle ukoclastic vasculitis と診断され，I型アレルギーとSjogren症候群に伴う血管炎の合併も認めている.Cr值も 1.2前後で推移し特に腎障害の進行も認めず, PSL10mg/dayにて維持されていた，1998年10月に 虫さされ痕に皮膚が潰瘍化し入院. IgE16000以上で慢性EBウイルス感染に伴うNK増多症を疑っ たが, EBVVCAIgG640倍, EBNA80倍, CD16+CD56+ 細胞6.7\%とNK細胞の増加を認めなかっ た. 再度, 皮盧生検を施行し, leukoclastic vasculitis と診断しPSL40mg/dayより加療して潰貆 は治痹した. EBER-1によるin situ hybridizationにても唾液腺, 腎, 皮盧の浸潤リンパ球に陽性 紐胞を認めなかった。 
W 21-3

SSA 抗体が陽性化し心等症を呈した原発性シェーグレン症候群の 1 例

O西成田 真 ${ }^{1}$, 中川美紀 ${ }^{1}$, 曰中栄一 ${ }^{2}$

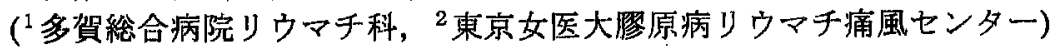

症例, 33 歳, 女性. 1995 年 11 月ごろより発熱, 肩, 手などの関節痛あり, 当科受診, 乾燥 症状むり，手，膝の関節炎あり. 胸腹部に理学的異常所見なし. 白血球数 $3040 / \mu 1$ と減少, 高 $\gamma$-グロブリン血症あり，IgG は $2030 \mathrm{mg} / \mathrm{dl}$ と上羿していた，ANA，抗 DNA 抗体は陰性，抗 SSA 抗体も陰性(オクタロニ一法，ELISA 法)：シルマー試検陽性で，口唇生検による唾液腺組織 像では，導营周囲の円形細胞浸潤が認められ原発性シェーグレン症候群と診断された。 1997 年 9 月より，動悸，呼吸困難，失神発作が出現. 胸部レントダンでは著明な心拡大を認めた。 心エコ 一では左室拡大と左室壁運動の著しい低下があり，EFも 20\%と低下し拡張型心筋症(DCM)に合 致する所見であった。この時期に IgG 值は 5841mg/dl と高值を示し，抗 SSA 抗体も $500 \mathrm{U} / \mathrm{ml}$ 以上(ELISA 法)と著明な上昇を認めた。利尿剤, 強心楽, 多量のステロイド剤の投与にも反応せ ず死の転帰をたどった，本症例山，アルコール歴，家族歷など制く，エコーウイルス，コクサッ キーウイルスなどの感染も否定的で, 原病による心觔症の可能性が推測された。シェーグレン症 候群における心䋉症はきわめて希であり，抗 SSA 抗体の上昇を伴った点でも示唆に富む症例と考 えられた。

\section{W 21-4}

ホルネル症候群・ぶどう膜炎・脾腫を呈し抗 T 3 抗体陽性の橋本病を合併した $\mathrm{S}$ $\mathrm{L}$ Eの 1 例

○澤木秀明, 村田進, 林雅子, 武内徹, 槙野茂樹, 坂根貞樹, 高松順太 (大阪医科大学第一内科)

症例は 44葴女性。平成3年被髪部の皮疹、脱毛出現。翌4年より日光過敏。6年冬右手首 関節痛、翌7年両㮏両足関節痛出現。8年他院にて慢性甲状腺炎と診断される。10年1月レ イノ一症状出現。3月左胸水にて他院入院、結核として治療され改善するも、その際、抗 dsDNA抗体陽性、低補体価であった。8月被姴部皮疹、発熱、顔面右半分の無汗症、瞳孔不 同 (左>右)出現し10月5日入院となった。入院時、ホルネル症候群、ブドウ膜炎、脾腫、

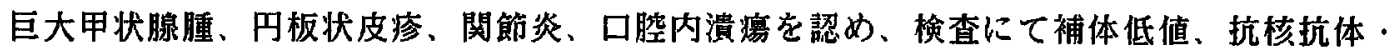

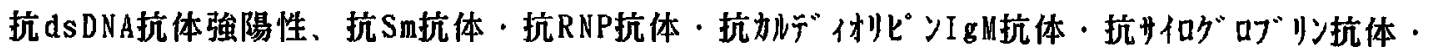
抗マイクログーム抗体陽性であり既往の光線過敏症、胸膜炎も併せ橋本病合併SLEと診断した。 T3 $380 \mathrm{ng} / \mathrm{dl}$ 、T4 $8.1 \mu \mathrm{g} / \mathrm{dl}$ 、TSH $1.06 \mu \mathrm{U} / \mathrm{ml}$ とeuthyroidにもかかわらずT3高值であ り模索したところ抗T3抗体陽性であった。11月2日よりプレドニン40mgより加療開始し、 速やかに症状は改善し抗「了抗体も陰性化した。本例はホルネル症候群・ぶどう膜炎・脾腫 · 抗 丁抗体と著明な甲状腺腫を伴った橋本病、抗リン脂筫抗体陽性と言った多くの自己免疫 病態を合併しており、しかも、比較的mi 1dな治療に良好に反応した興味深い症例と考えら れた。また、抗T3抗体陽性のSLEは過去2例報告があるが、いずれも本例と同様に橋本病合 併例である。T3高値の橋本病合併SLEでは抗T3抗体の検索も必要と考える。 


\section{W 21-5}

phenytoinが治痖抵抗性の要因になったRAの1症例

○棋田紀子夫夫、乳原善文、白矢勝子、松下芳雄、額浩一、田上哲夫、北村曜子、横田雅史、 香取秀幸、竹本文美、原茂子、山田明，

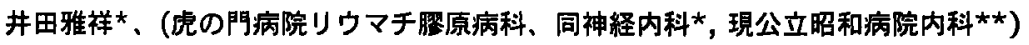

【症例】44才女性。【主訴】多発性関節炎、発熱。【既往歴】出生時仮死。【現病歴】幼少時より epilepsyに対して複合抗てんかん薬を服用していた。1995年右手関節骨折を契機に、発熱、点状出血 出現。胸腹水、蛋白尿、血小板減少、貧血を呈した。phenytoinによるSLEを疑い、薬栋の中止ととも にパルス洗法を含んだステロイド療法(methylprednisolone, mPSL)を行ない轻快し、徐々に潮減し中 止したが、epilepsyに対し他刘での管理困難になりphenytoinが再開された。1998年4月大䦕節中心の 多発関節炎が出現したか、mPSL16mgの投与にて柽快。1998年12月より同樣の開節资、発熱が出現し 入院。入院時、CRP $22.5 \mathrm{mg} / \mathrm{dl}$, ESR 63mm/hr, lgM-RF $52 \mathrm{U} / \mathrm{ml}$ あ゙り、 mPSLを最大64mgに増 田しパルス療法を2回施行し、免疫抑制剂等を併用するも効果なし。この時点で血中mPSL濰度を測定し たところ、感度以下であったため、抗てんかん蕜がその原因であると考え、epilepsyに注意しながらま ずphenytoin300mgを約2ヶ月かけて渐減し中止し、sodium valproateに切り替えた後より、関節炎 症状、CRP、RFの著明な改善がえられた。【結論】phenytoinの中止により臨床所見の改善がえられた ことから、種々の抗てんかん薬のうち、本症の病態にphenytoinが強く関与していることが推察された。 【考察】ステロイド唁を大量に投与していたにもかかわらず、その血中摆度が感度以下であったことを 考え合わせ、phenytoinがステロイド琂を中心とした免疫抑制用の代謝を方進させたことによって治噫 抵抗性になったと考えられた。 